ZOOLOGIA 27 (4): 569-576, August, 2010

doi: $10.1590 /$ S1984-46702010000400009

\title{
Misplaced Neotropical Agaristinae (Lepidoptera, Noctuidae), with descriptions of new taxa
}

\author{
Vitor O. Becker \\ Reserva Serra Bonita, Caixa Postal 001, 45880-970 Camacan, BA, Brazil. E-mail: becker.vitor@gmail.com
}

\begin{abstract}
The following taxa, formerly misplaced, are transferred to Agaristinae based on characters of genitalia and, especially, on the presence of a prominence on the frons of head, a character absent in the Arctiinae: Acyclania Dognin, 1911, Chlanidophora Berg, 1877 and Graphelysia Hampson, 1911 from the Arctiinae; Cyanohypsa Giacomelli, 1911 from the Pericopinae [= Pericopini]; Oxytaphora Dyar, 1917 from the Amphipyrinae; Cabralia judsoni Schaus, 1933 from the Ophiderinae [= Catocalinae] to Rhosus Walker, 1854 [= Rhosus judsoni (Schaus) comb. nov.]; Caularisia gen. nov. is proposed to include C. zikani (Schaus, 1933) comb. nov.; Gerra radiata sp. nov. is described from Brazil; Caridarctia Hampson, 1901 syn. nov. [= Chlanidophora Berg]; Chlanidophora mariae Köhler, 1924 syn. nov. [= Acyclania tenebrosa Dognin], Aucula particolor Dyar, 1914 syn. nov. and Gerra pulchra Draudt, 1919 syn. nov. [= Darcetina sublata (Walker, [1865])]; lectotypes are designated for Caularis zikani Schaus, 1933 and for Aucula particolor Dyar, 1914.
\end{abstract}

KEY WORDS. Arctiinae; Amphipyrinae; Catocalinae; Pericopini; new taxa.

The taxa treated here were originally misplaced, mostly in the Arctiidae [= Arctiinae] and in subfamilies of Noctuidae, or in incorrect genera within the Agaristinae. Their proper placement and affinities are discussed here. Most of the type-material was examined, lectotypes are designated, synonymies established, one new genus and one new species are proposed, and illustrations provided to enable their identifications.

The material studied here is deposited in the following institutions: The Natural History Museum, London (BMNH), Museo Nacional de Historia Natural Bernardino Rivadavia, Buenos Aires (MNHN), National Museum of Natural History, Washington (USNM) and in the author's collection, Reserva Serra Bonita, Camacan, Bahia (VOB).

\section{TAXONOMY}

\section{Acyclania Dognin}

Acyclania Dognin, 1911. Type-species: Acyclania tenebrosa Dognin, 1911: 15, by original designation.

Remarks: originally described in the Arctiidae [Arctiinae], it was placed by Hampson (1920), next to Chlanidophora Berg. SEITz (1925) synonymized it under Caridarctia Hampson, however, WATson (1973), reinstated it as a valid, distinct genus. It was excluded from the Arctiidae by WATson \& Goodger (1986), following the suggestion of the present author. The presence of a triangular-pointed prominence or tubercle on the frons of the head excludes this genus from the Arctiidae. The genus is closely related to Chlanidophora but differs mainly in the shape of the genitalia which have long valvae with parallel margins, bearing asymmetric processes of sacculus, and uncus triangular in crosssection. These characters are apomorphic to the genus.

\section{Acyclania tenebrosa Dognin}

Figs $1-3,15$

Acyclania tenebrosa Dognin, 1911: 15; Hampson, 1920: 491, fig. 99; Watson, 1973: 45, pls. 27a, 81c. Holotype male, Argentina, Misiones: San Ignacio [Haut-Parana], VIII, Wagner leg. (USNM, no. 30443), genitalia slide A[lan] W[atson] 538 [examined].

Chlanidophora mariae Köhler, 1924: 14. Holotype female, [ARGentina], Misiones [no further data] [ex. Col. Breyer] [not examined]. Syn. nov.

Caridarctia tenebrosa (Dognin); Seitz, 1925: 473.

Material studied: 5 males, 3 females, 3 genitalia slides. BRAsIL, Distrito Federal: Planaltina (1000 m), 2 males, 2 females, 24.II.1977, 15.X.1982, 5.XI.1982, Becker leg. (VOB 19744, 40447, 40652), genitalia slides VOB 95, 96; Minas Gerais: Nova Lima (850 m), female, 20.X.1994, Becker leg. (VOB 92873); Sete Lagoas (720 m), male, 15.IV.1974, Becker leg. (VOB 2351) (VOB).

Remarks: the males in the author's collection match the type of $A$. tenebrosa, including genitalia, and the females match the figure of C. mariae in the original description (KöHLER 1924: pl. 1, fig. 1 ; pl. 6, fig. 10).

\section{Acyclania schadei Schaus}

Figs 4, 16

Acyclania schadei Schaus, 1927: 76; Jörgensen, 1935: 108, pl. 3, figs 24, 25; Watson, 1973: 42, pls. 27b, 81a,b. Holotype male, PARAGUAY, [San Pedro], Molinasque, III.1926, Schade leg. (USNM, no. 33197), genitalia slide A[lan] W[atson] 537 [examined].

Material studied: 2 males, 2 genitalia slides. BraziL, Ceará: Guaramiranga (1000 m), male, 9.IV.1994, Becker leg. (VOB 91779), genitalia slide VOB 1782 (VOB). 
Remarks: this species is similar to A. tenebrosa but darker; antennal pectination shorter and forewing narrower. It also differs in the shape of genitalia (Fig. 16) with processes of sacculus much reduced. Rare in collections. The Brazilian record extends its range considerably. Both collecting localities are seasonally dry, which explains its rarity in collections as moth collecting in the dry areas of South America are noticeably neglected. According to Jörgensen (1935), Schade reared the gregarious larvae on Heteropteryx argyrophaea (Malpighiaceae).

\section{Caularisia gen. nov.}

Type-species: Caularis zikani Schaus, 1933.

Diagnosis. This is the only genus belonging to the New World Agaristinae with plain golden-orange hind wings and pectinate antennae; the valvae bearing a broad, thin pointed clasper is unique in the Agaristinae.

Description. Palpi short, porrect, $3^{\text {rd }}$ segment vestigial. Proboscis $4 \mathrm{x}$ eye diameter. Frons with conical, truncate prominence. Antennae bipectinate; pectination $4 \mathrm{x}$ diameter of flagellum. Fore wings, $17 \mathrm{~mm}$ long, elongate; apex rounded, termen, tornus and dorsum evenly round; chocolate brown, irrorated with thin, white scales; markings indistinct; $\mathrm{M} 3$ and $\mathrm{CuA} 1$ free. Hind wings plain golden orange; $\mathrm{Rs}+\mathrm{M} 1$ and $\mathrm{M} 3+\mathrm{CuA} 1$ connate

Genitalia male. Uncus thin, long, evenly bent ventrad; tegument thin with two distal, lateral, thin, short, hooked projections; vinculum thin, narrow; juxta a shield-shaped plate, concave distally; valvae long, oval; sacculus long, narrow, reaching near tip of valvae; clasper broad basally, long, tapering distad, tip bent ventrad; aedoeagus short, thick, $2 \mathrm{x}$ diameter; vesica armed with very strong, basally broad, long cornutus, almost lengh of aedoeagus.

Etymology. Derived from Caularis Walker.

\section{Caularisia zikani (Schaus) comb. nov.} Figs 5, 21

Caularis zikani Schaus, 1933: 373; Poole, 1989: 227. Lectotype male, [Brazil, Rio de Janeiro: [Itatiaia]] "Prov. Rio", Zikán leg., genitalia slide J[ohn] G. F[ranclemont] 197 (USNM), here designated [examined].

Material studied: 4 males, 2 genitalia slides. BraziL, São Paulo: São Luiz do Paraitinga, 2 males, 900 m, 12-17.XI.2001, Becker leg. (VOB 133555), genitalia slide VOB 1782 (VOB).

Remarks: this species is not congeneric with those currently in Caularis, neither with any other of the New World genera of Agaristinae. Readily distinguished from any other New World agaristine by the combination of reddish brown forewings and plain golden yellow hind wings.

Described from an unspecified number of specimens from "Campo Bello, Rio". Two specimens were traced in the USNM: the "Type" [see above], and another male labeled "Campo Belo, Rio, Zikán", here designated as paralectotype. With the removal of this species, Caularis becomes restricted to the Antilles.

\section{Chlanidophora Berg}

Figs 6, 17

Chlanidophora Berg, 1877: 9. Type-species: Chlanidophora patagiata Berg, 1877: 11, by monotypy.

Caridarctia Hampson, 1901: 452. Type-species: Arctia albicancellata Burmeister, 1878: 449, by original designation. Syn. nov.

Remarks: this genus, originally described in the Arctiidae, is closely related to Acyclania [see above for differences] and to Rhosus Walker, 1854. The round or conical head prominence excludes it from the Arctiinae, and distinguishes this genus from the former, and the long digital process of sacculus from the second. It has been treated in all major works on the Arctiinae (Hampson 1901, Seitz 1919) until excluded by Watson \& Goodger (1986) following the suggestion by the present author. Both Chlanidophora and Caridarctia have been considered distinct on the base of the shape of antennae and hind wing venation. In Caridarctia the antennae are strongly bipectinate, and Rs and M1 on hind wings connate, whereas the antennae are filiform, and Rs and M1 stalked in Chlanidophora. However, the characters of their male genitalia do not support this separation, as they are almost identical (Figs 17-18). Forbes (in BiezANKo et al. 1957), stated that "This [Chlanidophora] is probably a noctuid, certainly not an arctiid". Biezanko \& Guerra (1971) mentioned that the larvae of C. albicancellata (Burmeister), comb. nov., like those of Xanthopastis timais (Cramer, data), feed on the leaves and bulbs of several species of Amaryllidaceae [= Liliaceae], and for this reason included both in a new subfamily: Xanthopastinae [= Hadeninae, Glottulini]. Although both species present similarities in colour pattern and food preferences, $X$. timais has hirsute eyes and is a member of the Hadeninae. The larvae of $C$. patagiata were reared on Chloraea piquichen Lindl. (Orchidaceae) by Bourquin (1949). A third species, C. culleni Brèthes, 1908 belongs to this genus. Its description is not very accurate, the sex of the type-specimen is not indicated, and the illustration which accompanies the original description rather crude. However, according to them it is very likely that the type-specimen of $C$. culleni is only a female of C. patagiata.

\section{Cyanohypsa Giacomelli}

Figs 7, 26

Cyanohypsa Giacomelli, 1911: 31; Hering, 1925: 433; Watson, Fletcher \& Nye, 1980: 47. Type-species: Cyanohypsa stefanellii Giacomelli, 1911: 31, by original designation.

Material studied: 3 males, 1 genitalia slide. Argentina, $L a$ Rioja [no further data], 2 males, genitalia slide 51039 (USNM); BraziL, Goiás: Alvorada do Norte, male, 415 m, 11-14.XI.2003 (E. Emery leg.) (VOB 135067) (VOB).

Remarks: this monotypic genus was originally described in the Hypsidae [sensu Hampson (1898) which at the time included the Pericopinae (Arctiidae). It was retained in that sub- 

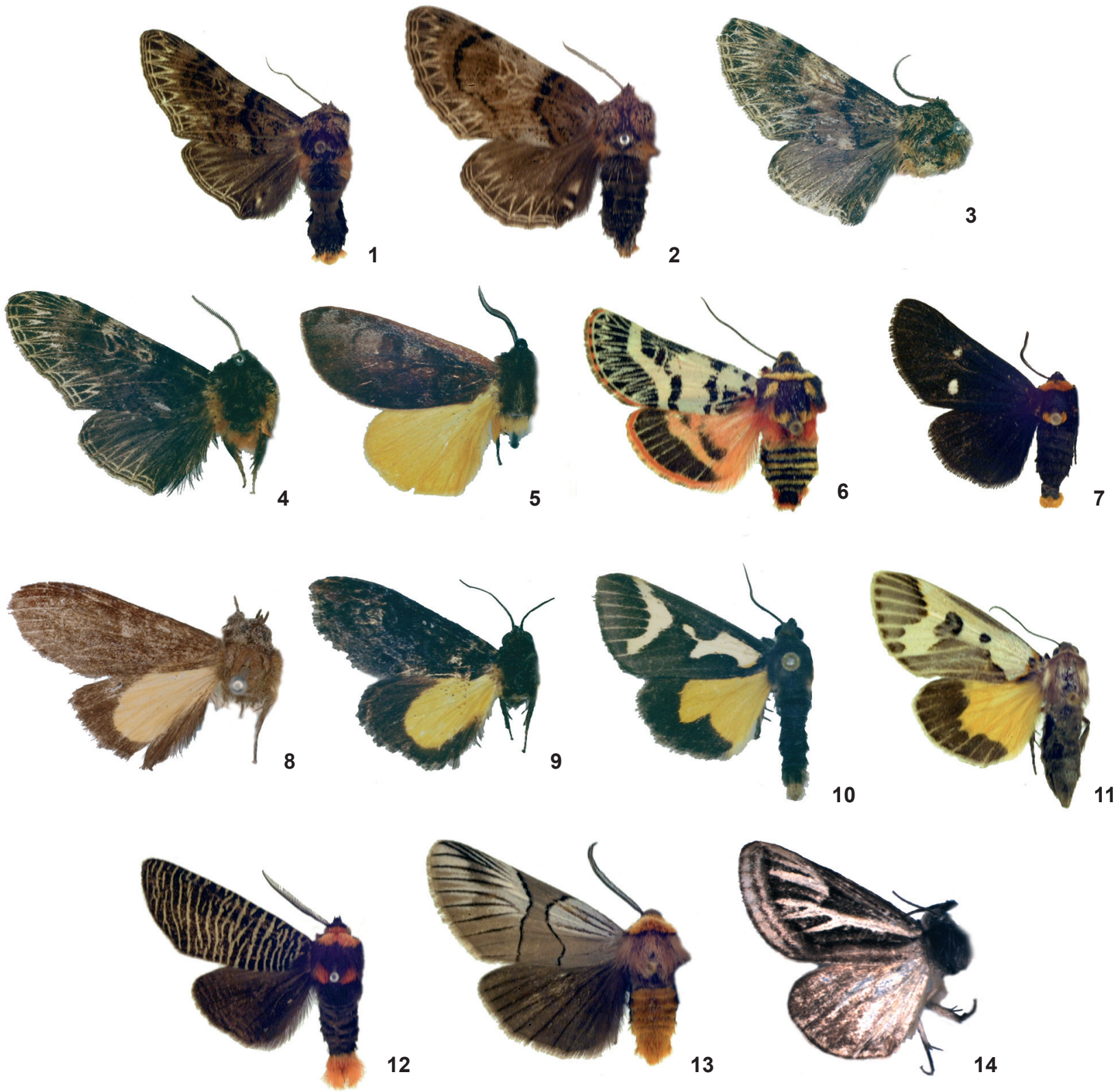

12
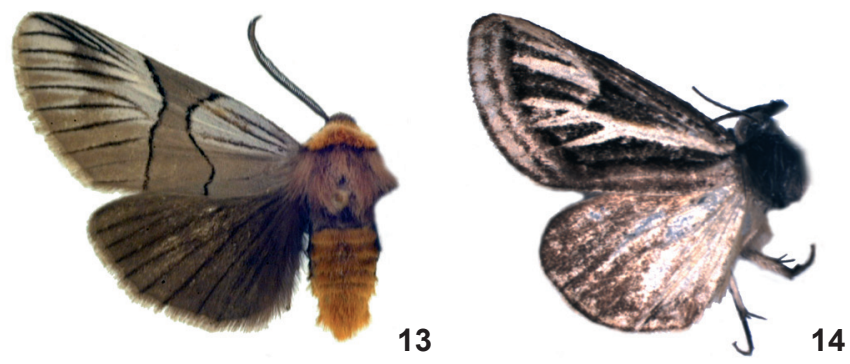

Figures 1-14. Agaristinae adults, right wings removed: (1-2) Acyclania tenebrosa male and female (Brazil); (3) A. tenebrosa holotype male, Argentina; (4) A. schadei holotype male, Paraguay; (5) Caularisia zikani lectotype male, Brazil; (6) Chlanidophora patagiata male, Argentina; (7) Cyanohypsa stefanellii male, Brazil; (8) Darcetina sublata holotype male, Brazil; (9) D. sublata lectotype male of Aucula particolor; (10) Gerra lunata male, Paraguay; (11) G. radiata sp. nov. paratype female, Brazil; (12) Graphelysia strigillata male, Brazil; (13) Oxytaphora delta male, Brazil; (14) Rhosus judsoni holotype male, Ecuador.

family by HeRING (1925: 433, pl. 61a), and excluded by WATSON \& GOODGER (1986), following the suggestion of the present author. The cylindrical, truncate prominence of head, and the peculiarly shaped male genitalia (Fig. 26) excludes it from the Arctiidae. The male genitalia resemble those of Oxytaphora Dyar [see below], but differs by its thin, rod-shape uncus.

The type-species was described from an unspecified number of specimens, not examined by the author. However, the specimens studied here, in the USNM, belong to a series, from the type-locality (ArgENTINA: La Rioja), apparently sent to Schaus 

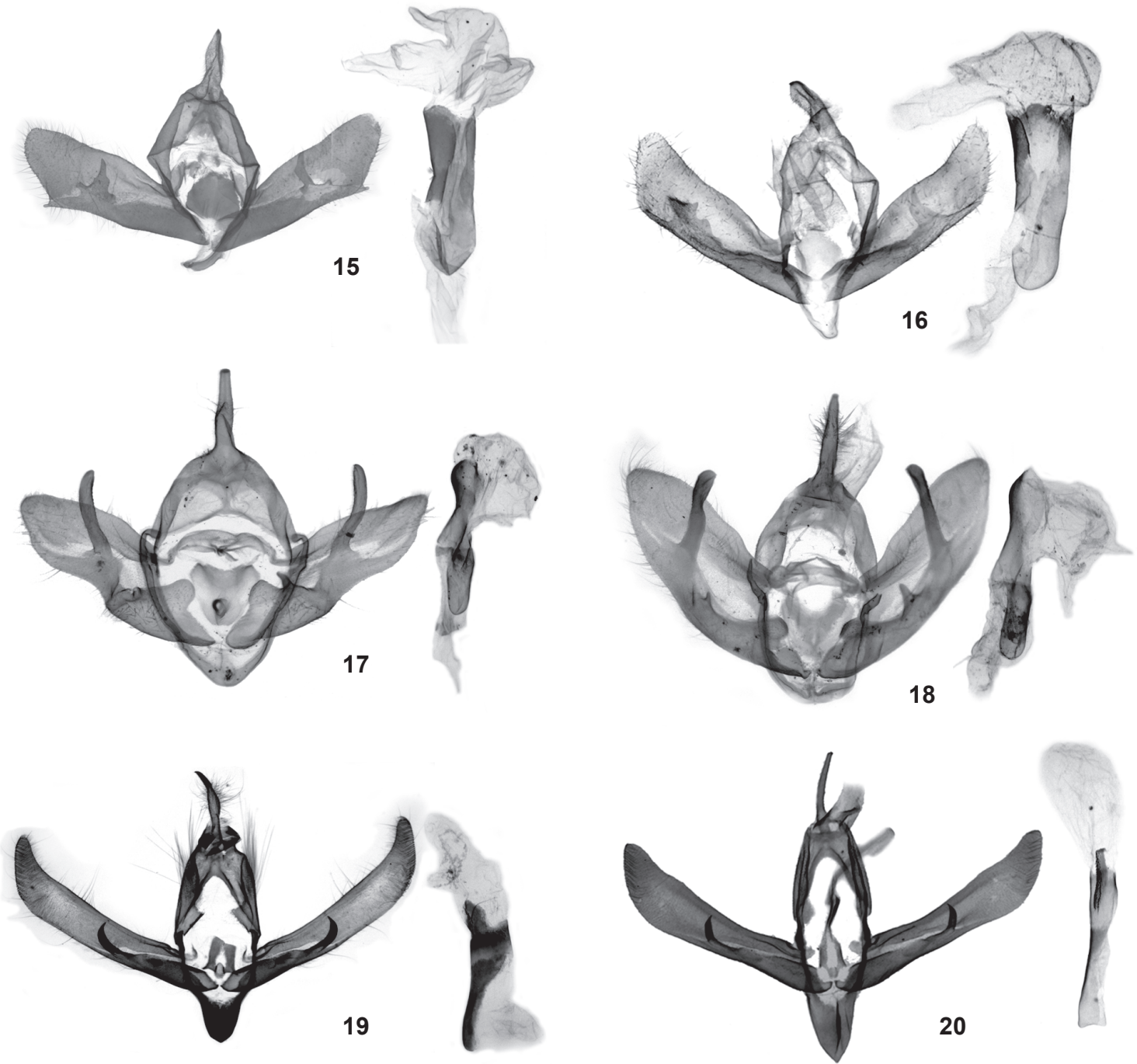

Figures 15-20. Agaristinae male genitália, aedoeagus removed: (15) Acyclania tenebrosa; (16) A. schadei; (17) Chlanidophora patagiata; (18) C. albicancellata; (19) Gerra radiata; (20) G. lunata.

by Giacomelli himself, and so, probably part of the original type-series. In the original description is suggested that the species is diurnal "Volaban sobre algunas Mimosa y cerca de las Jatropha...". The specimen illustrated here, which has the white dots on fore wings smaller than those on the Argentinian specimens, was also found flying during the day.

\section{Darcetina Felder}

Darcetina Felder, 1874: pl. 99. Type-species: Darcetina cinerosa Felder, 1875: pl. 99, fig. 19, by monotypy.

Remarks: this monotypic genus was described in the Arctiidae and apparently overlooked by all major authors until NYE (1975), listed it in the Agaristinae, recognizing D. cinerosa as a junior synonym of Bepara sublata Walker, [1865] (see be- low), an action apparently overlooked by Todd \& Poole (1981). This genus shares with Aucula authors the yellow oval area of hind wings and complex male genitalia (Fig. 23), however, the filiform antennae and dark gray and iridescent blue on fore wings excludes it from this genus. The broadly expanded tegumen is unique in the Agaristinae.

\section{Darcetina sublata (Walker)}

Figs 8, 9, 23

Bepara sublata Walker, [1865]: 143. Holotype male, [BraziL, Amazonas: Tefé] 'Ega', [Bates leg.] (BMNH) [image examined]. Darcetina cinerosa Felder, 1874: pl. 99, fig. 19. Lectotype female, [Brazil]: R. Amazonas (BMNH), here designated [not examined]. Synonymized by Nye, 1975: 150. 


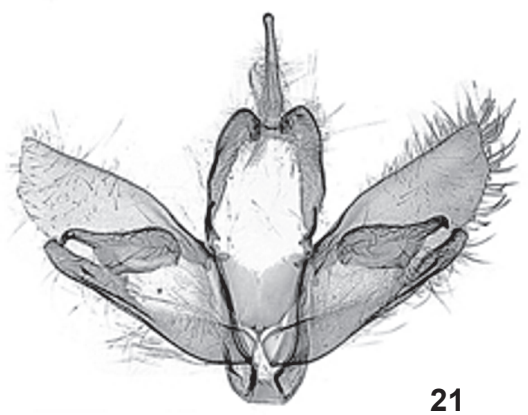

21
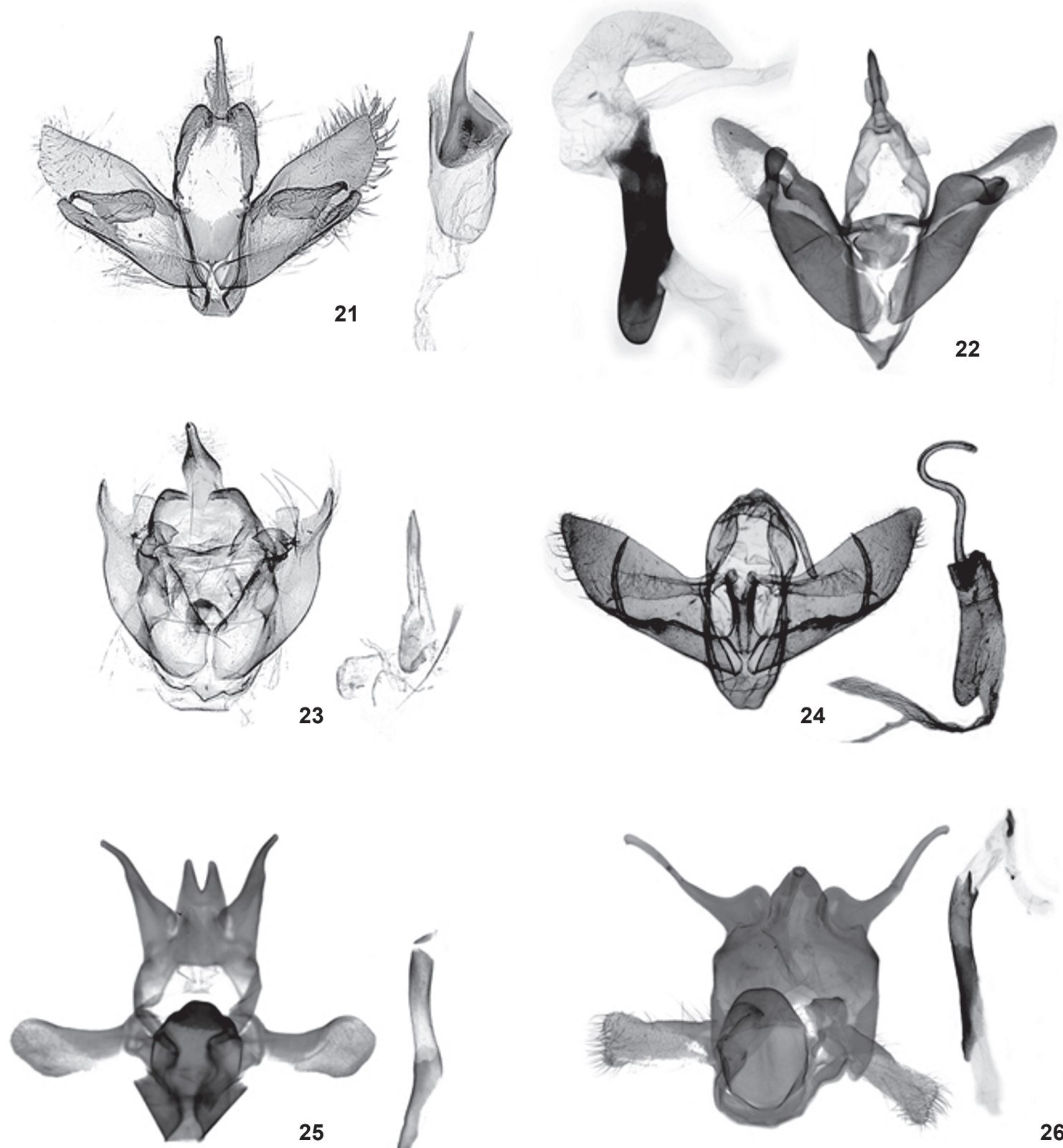

25
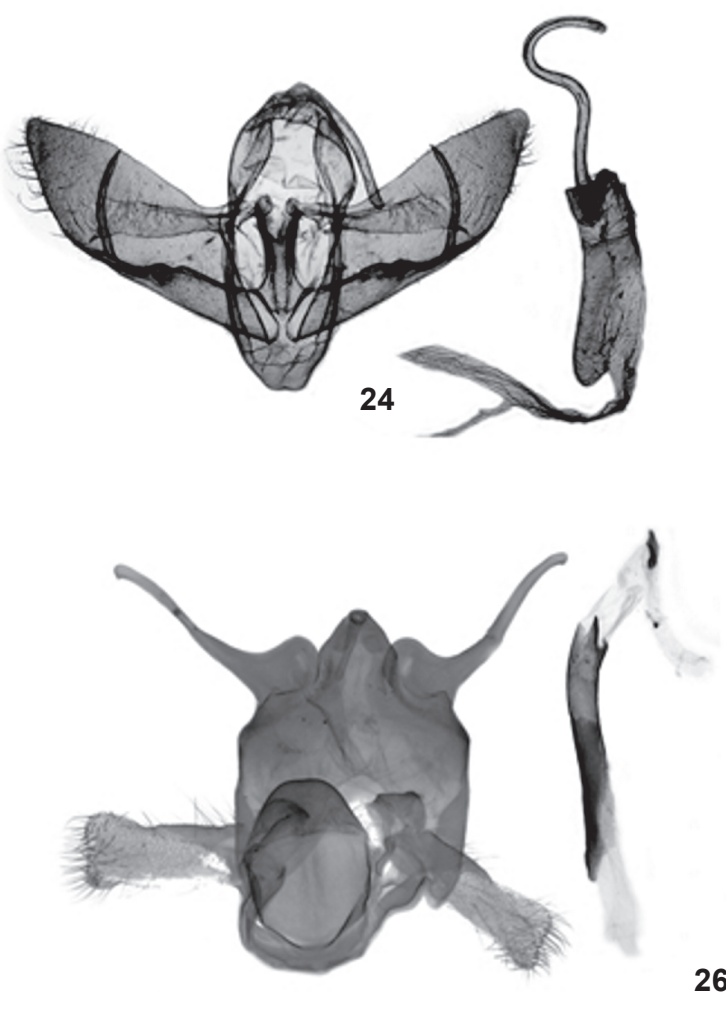

Figures 21-26. Agaristinae male genitália, aedoeagus removed: (21) Caularisia zikani, lectotype; (22) Graphelysia strigillata; (23) Darcetina sublata, lectotype of A. particolor; (24) Rhosus judsoni, holotype; (25) Oxytaphora delta; (26) Cyanohypsa stefanellii.

Aucula sublata (Walker); Hampson, 1910: 423, pl. 146, fig. 6; Draudt, 1919: 12, pl. 1h; Kiriakoff, 1977: 21.

Aucula particolor Dyar, 1914: 184. Lectotype male, PANAMA: La Chorrera, V.1912, Busck leg. (USNM), genitalia slide J[ohn] G. F[ranclemont] 283, here designated [examined]. Syn. nov. Gerra pulchra Draudt, 1919: 184. Holotype male, Bolivia, [ $\mathrm{La}$ Paz]: Mapiri [not traced]. Syn. nov.
Darcetina sublata (Walker); Nye, 1975: 150; Todd \& Poole, 1981: 194.

Material studied: 18 males, 3 females, 2 genitalia slides. BraziL, Rondônia: Porto Velho, 12 males, 3 females, 24-30.IV.1989, Becker leg. (VOB 62651); Cacaulândia, 5 males, XI. 1991, 1520.IV.1996, 26-30.V.1998, Becker leg. (VOB 78806, 107311, 116985), genitalia slide VOB 1779; ECUADOR, Napo: Misauhalli, 450 m, male, XII.1992, Becker leg. (VOB 100997) (USNM, VOB). 
Remarks: B. sublata was originally described in the Arctiidae [Bepara Walker, [1865] is a junior synonym of Virbia Walker, 1854, a true Arctiinae], transferred to Aucula Walker, 1862, a genus originally described in the Lithosiidae [= Lithosiinae: Arctiidae], and included in the Acronyctinae [Acronictinae] by HAMPSON (1910) and in the Agaristinae by DraudT (1919); it was transferred by Nye (1975) to Darcetina Felder, 1874, a genus also originally described in the Arctiidae, as the senior synonym of $D$. cinerosa Felder, 1874, the typespecies. A. particolor was originally included in the Acronyctinae [= Acronictinae] (Noctuidae), and G. pulchra in the Agaristinae.

The series of specimens in the author's collection, match the colour image of the type (Fig. 8); the syntypes of $A$. particolor (Fig. 9); the figure of G. pulchra in Draudt (1919), and a female specimen from Peru, Madre de Dios, in the USNM, bearing an identification label in HAMPSON's hand writing "Aucula sublata Wkr". The colour illustration of the type of D. sublata in HAMPSON (1910: pl. 146, fig. 6) is rather crude, and likely copied in DraUdT (1919: pl. 1h) who apparently did not examine the type specimen. As he also overlooked the descriptions of both $D$. cinerosa and $A$. particolor it explains why he described the species again. The type of G. pulchra was presumably deposited in Draudt's collection, destroyed in the World War II.

\section{Gerra radiata sp. nov.}

Figs 11,19

Diagnosis. The mostly gray wings, crossed with the contrasting white veins are unique among the New World Agaristinae.

Material examined: holotype male, BrAsIL, Bahia: Jequié, 600-750 m, 11-22.XI.1995, Becker leg. (VOB 105481), genitalia slide VOB 3644; paratypes, 2 females, same data as holotype (VOB).

Description. Male $16 \mathrm{~mm}$, female $18 \mathrm{~mm}$. Sexes similar. Head mouse-gray; antennae bipectinate, pectination 3x diameter of flagellum. Thorax whitish; patagia and tegulae bordered gray posteriorly; legs mouse-gray. Fore wings mouse-gray crossed with white veins; broad, irregular, white area above cell from base to before apex, expanding towards termen from $\mathrm{M} 2$ to $\mathrm{CuA} 2$ and obliquely from lower margin of mid cell towards base of dorsum; base dark gray irregularly bordered outside with deep yellow; reniform and orbicular spots dark gray, former whitish inside. Hind wings pale yellow; broad mousegray margin from costa to tornus, crossed with white veins. Cilia white in both wings. Abdomen mouse-gray.

Genitalia male. Uncus long, thin, slightly expanded medially, sharp pointed apically, evenly bent ventrad, dorsally covered with long setae; tegumen broad, with long setae laterally; saccus shield shaped, broadly triangular basally; juxta subquadrate plate, basal angles expanded into sharp points. Valvae very long, narrow, $6 \mathrm{x}$ times as wide, margins parallel to 5/6 length, tapering and bent dorsad towards apex; aedoeagus $3 \mathrm{x}$ times diameter, cylindrical; base of vesica slightly scobinate ventrally.

Remarks. Closely related to G. lunata (Köhler, data) (Figs 10 and 20), from Argentina, but this has forewings with the white areas much reduced and veins less contrasting. Etymology. From the Latin radiatus = rayed.

\section{Graphelysia Hampson \\ Figs 12,22}

Graphelysia Hampson, 1911: 408. Type-species: Elysius strigillata Rothschild, 1910: 187, by original designation.

Material examined: 6 males, 8 females, 2 genitalia slides. Brasil, Bahia: Jequié, 600-750 m, male, female, 11-22.XI.1995, Becker leg. (VOB 105484); Distrito Federal: Planaltina, 1000 m, female, 24.IX.1976, Becker leg. (VOB 18206), genitalia slide 3549; Minas Gerais: Unaí, 650 m, male, female, 21.X.1995, Becker leg. (VOB 117423); Mato Grosso do Sul: Corumbá, 600 m, male, 20-22.IV.1985, Becker leg. (VOB 63498), genitalia slide VOB 3650; Mato Grosso: Chapada dos Guimarães, 800 m, 2 males, female, 26.X.1993, 20.XI.1994, 25-30.XI.1995, Becker leg. (VOB 88961, 93691, 110691); Rondônia: Porto Velho, male, 30.IV.1989, Becker leg. (VOB 62150); São Paulo: Paranapanema, 2 females, 24.X.1968, Becker leg. (VOB 2367, 2369); Luiz Antônio, Jataí, female, 500 m, 13-18.X.2001 Becker leg. (VOB 133108); Ecuador, Napo: Misahualli, female, 450 m, XII.1992, Becker leg. (VOB 100998) (VOB).

Remarks: described in the Arctiinae, this monotypic genus was transferred to the Acontiinae (Noctuidae) by FORBES (1924), who stated that "Altogether the connection with the Acontiinae, Noctuidae is unmistakable, though no genus known to me is at all close". This action was presumably overlooked by most subsequent authors: HERING (1925) included it in the Pericopinae; Rego-Barros (1969) redescribed and returned it to the Arctiidae [= Arctiinae]; WATson et al. (1980) listed it in the same subfamily. The genus was not included in the Arctiidae by Watson \& GoOdger (1986), following the suggestion by the present author. The conical, pointed prominence on the head excludes it from the Arctiinae. The male genitalia (Fig. 12) are intermediate between Xerociris Grote, 1863 and Eudryas Boisduval, 1836. The valvae are similar to those of the former with processes of sacculus large and broad, and uncus like that of the later, bearing digital socii at base. Its strigulate pattern is unique in Agaristinae.

\section{Oxythaphora Dyar}

Figs 13, 25

Oxythaphora Dyar, 1917: 50. Type-species: Oxytaphora delta Dyar, 1917: 51, by monotypy.

Material examined: 4 males, 15 females, 3 genitalia slides. BrasiL, Alagoas: Ibateguara, male, 400 m, 10-20.III.1994, Becker leg. (VOB 90137); Bahia: Jequié, 600-750 m, 7 females, 1122.XI.1995, Becker leg. (VOB 105476), genitalia slide VOB 3665; Ceará: Boa Viagem, 200 m, 3 males, 8 females, 12.IV.1994, Becker leg. (VOB 92188), genitalia slides VOB 3195, 3664 (VOB).

Remarks: this monotypic genus was described in the Acronyctinae [= Acronictinae] sensu HAMPSON (, which included 
the Amphipyrinae, and treated in the last subfamily by DRAUDT (1926), again in the Acronictinae by NyE (1975) and back to the Amphipyrinae by Poole (1989). According to the male genitalia (Fig. 25) it is related to Cyanohypsa [see above], but its broad, forked uncus is unique in the Agaristinae.

\section{Rhosus judsoni (Schaus) comb. nov.}

Figs 14,24

Cabralia judsoni Schaus, 1933: 385; Poole, 1989: 182. Holotype male, EcuAdor: Huigra, 4000 ft, II.1930, W. Judson Coxey leg. (USNM, no. 34415), genitalia slide USNM 46685 [examined].

Remarks: Cabralia Moore (1882: 374) was described in the Glottulidae [= Noctuidae: Glottulinae] a subfamily which was merged with the Hadeninae by Hampson (1905), but he did not include Cabralia among them. Schaus (1933) described C. judsoni just after Herminodes Guenée, 1852, a genus belonging to the Ophiderinae and NYE (1975) listed Cabralia in the same subfamily. It is very likely that both authors followed the arrangement of the BMNH noctuid collection as left by Hampson. C. judsoni is not congeneric with C. trifasciata Moore, 1882, neither an Ophiderinae [= Catocalinae]. According to its characters it belongs to the Agaristinae, closely related to the species currently in Gerra Walker and in Rhosus Walker, 1854. It is being included in the last genus based on the presence of a long, strong cornutus on the vesica, a character present in Rhosus but absent in Gerra species (Fig. 24). Only the holotype specimen is known.

\section{ACKNOWLEDGEMENTS}

Without the collaboration provided by the following persons this work could not be finished. Patricia Gentili (USNM), provided literature and information about type material; Olaf H.H. Mielke, Universidade Federal do Paraná, James Miller (USNM) and Andrei Sourakov, University of Florida, Gainesville, provided copies of literature; Michel Pogue (USDA), provided images and data of type specimens; Klaus Sattler (BMNH) provided type-specimens data; Inge Willems, Porto Seguro, Bahia prepared the plates; Anthony Raw, Universidade Estadual de Santa Cruz, read and corrected the manuscript. The Conselho Nacional de Desenvolvimento Científico e Tecnológico provided a grant (Proc. 478567/2004-9) to purchase optical equipment.

\section{LITERATURE CITED}

Berg, C. 1877. Beiträge zu den Lepidopteren Patagoniens. Bulletin de la Société Impériale des Naturalistes de Moscou 52: 1-22.

Biezanko, C.M. \& M.S. Guerra. 1971. Contribuição ao estudo de Xanthopastis timais Stoll, 1782, importante praga das amarilidáceas (Lepidoptera, Heterocera, Noctuidae). Arquivos do Museu Nacional, Rio de Janeiro 54: 267-272.

Biezanko, C.M.; A. Ruffinelli \& C.S. Carbonell. 1957. Lepidoptera del Uruguay. Revista de la Facultad de Agronomia 46: 1152.

BRÈTHES, J. 1908. Chlanidophora culleni uma nueva mariposa argentina. Annales del Museo Nacional de Buenos Aires 16: 45-47.

Bourquin, F. 1949. Notas sobre la metamorfosis de Chlanidophora patagiata Berg, 1877, Lep. Fam. Arctiadae. Acta Zoologica Lilloana 7: 393-394.

Burmeister, C.H.C. 1878. Description physique de La République Argentine 5: 1-524.

Dognin, P. 1911. Hétérocéres nouveaux de l'Amerique Du Sud. III. Rennes, Oberthür, 66p.

Draudt, M. 1919. Agaristidae, p. 3-13. In: A. Seitz (Ed.). Die Gross-Schmetterlinge der Erde. VI. Stuttgart, Alfred Kernen.

Draudt, M. 1925-1927. Amphipyrinae, p. 207-330. In A. Seitz (Ed.). Die Gross-Schmetterlinge der Erde. VI. Stuttgart, Alfred Kernen.

Dyar, H.G. 1917. A new noctuid from Brazil (Lepidoptera, Noctuidae, Acronyctinae). Insecutor inscitiae menstruus 5: 50-51.

Dyar, H.G. 1914. Report on the Lepidoptera of the Smithsonian Biological Survey of the Panama Canal Zone. Proceedings of the United States National 47: 139-350.

Felder, C. 1874. [Arctiidae]. In: C. Felder \& A.F. Rogenhofer (Eds). Reise Osterreichischen Fregatte Novara. Zoologischer Theil. II (2). Wien, Carl Gerold's Sohn, pls 75-120.

Forbes, W.T.M. 1924. The family position of Graphelisia (Lepidoptera). Psyche 31: 146-147.

Giacomelli, E. 1911. Lepidópteros riojanos nuevos ó poco conocidos. Anales de la Sociedad Científica Argentina 72: 19-40.

Hampson, G.F. 1898. Catalogue of the Lepidoptera Phalaenae in the British Museum. I. London, Taylor \& Francis, 559p.

Hampson, G.F. 1901. Catalogue of the Lepidoptera Phalaenae in the British Museum. III. London, Taylor \& Francis, 690p.

Hampson, G.F. 1905. Catalogue of the Lepidoptera Phalaenae in the British Museum. V. London, Taylor \& Francis, 634p.

Hampson, G.F. 1910. Catalogue of the Lepidoptera Phalaenae in the British Museum. IX. London, Taylor \& Francis, 552p.

Hampson, G.F. 1920. Catalogue of the Lepidoptera Phalaenae in the British Museum. Suppl. II. London, Taylor \& Francis, 592p.

Hering, M. 1925. Pericopinae, p. 425-455. In: A. Seitz (Ed.). Die Gross-Schmetterlinge der Erde. VI. Stuttgart, Alfred Kernen.

Jörgensen, P. 1935. Lepidópteros nuevos o raros de la Argentina y del Paraguay. Anales del Museo Argentino de Ciencias Naturales 38: 85-130.

Moore, F. 1882. Family Glottulidae. In: E.D. Jonks. Metamorphosis of Lepidoptera from Santo Paulo, Brazil. Proceedings of the Literacy and Philosophical Society of Liverpool 36: 325-377. NYE, I.W.B. 1975. The generic names of moths of the World. 
London, British Museum (Natural History), 568p.

Poole, R.W. 1989. Lepidopterorum catalogus (new series). Fasc. 118, Noctuidae. 1-3, 1314p.

Rego-Barros, A.R. Do. 1969. Contribuição ao estudo da família Arctiidae, sobre o gênero Graphelysia Hampson, 1911. Boletim do Museu Nacional (Nova Série) 268: 1-11.

Rothschild, L.W. 1910. Descriptions of new Arctianae in the Tring Museum. Novitates Zoologicae 17: 172-188.

Schaus, W. 1927. New species of Lepidoptera from South America. Proceedings of the Entomological Society of Washington 29: 73-82.

Schaus, W. 1933. New species of Heterocera in the National Museum, Washington. Annals and Magazine of Natural History (Ser. 10) 12: 368-387.

Seitz, A. 1919-1925. Spilosomini. In: A. Seitz (Ed.) Die Gross-
Schmetterlinge der Erde. VI. Stuttgart, Alfred Kernen, p. 306-325, 471-474.

WALKER, F. 1865. List of the specimens of lepidopterous insects in the collection of the British Museum. XXXI. London, Edward Newman, 321p.

WaTson, A. 1973. An illustrated catalog of the neotropic Arctiinae types in the United States National Museum (Lepidoptera: Arctiidae). Part II. Smithsonian contribution to Zoology 128: $1-160$.

WATSON, A.; D.S. Fletcher \& I.W.B. Nye. 1980. The generic names of the moths of the World. London, British Museum (Natural History), 228p.

Watson, A. \& D.T. Goodger. 1986. Catalogue of the Neotropical tiger-moths. Occasional papers on systematic Entomology 1: 1-71.

Submitted: 07.VII.2009; Accepted: 27.VI.2010.

Editorial responsibility: José A. Rafael 